\title{
Digital billboards and road safety
}

\author{
K. Domke ${ }^{1}$, K. Wandachowicz ${ }^{1}$, M. Zalesińska ${ }^{1}$, S. Mroczkowska ${ }^{1}$ \\ \& P. Skrzypczak ${ }^{2}$ \\ ${ }^{I}$ Poznan University of Technology, \\ Institute of Electrical Engineering and Electronics, Poland \\ ${ }^{2}$ City Road Administration Poznań, Poland
}

\begin{abstract}
Electroluminescent diodes have become increasingly popular on outdoor billboards for the last few years, all over the world. Digital billboards with electroluminescent diodes are large, have high luminance and display dynamically changing images. Billboards located near streets are a potential threat to traffic safety. The paper presents requirements for such billboards, the results and analysis of measurements of selected billboards located in Poznan, Poland, as well as conclusions and recommendations for large size billboards with light emitting diodes located in the vicinity of roads and intersections.

Keywords: light engineering, digital billboards, road safety.
\end{abstract}

\section{Introduction}

With the development of the technology of light emitting diodes (LED), large size billboards with electroluminescent diodes have come to our towns. These billboards are usually large, have high luminance and show dynamically changing images. Car, bus and rail vehicle drivers complain that glaring billboards located in their field of vision are uncomfortable to look at and interfere with normal driving tasks, especially in the evening and at night. Billboards located near streets are a potential threat to traffic safety.

The current Polish standards on outdoor lighting and road lighting specify no explicit requirements for this type of billboards. The currently valid requirements specify maximum luminance and luminous intensity values of signs, including billboards emitting light (or illuminated ones). However, the location of the billboard towards the observer, its angular diameter, distance from the main 
direction of observation and dynamic change of luminance related to displayed images (fig. 1) are not taken into account.
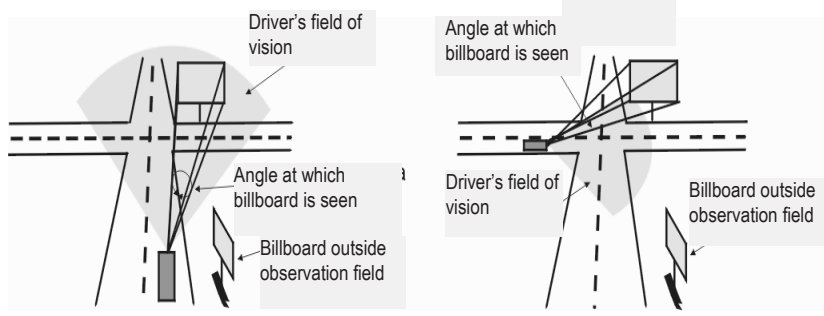

Figure 1: Location of the billboard in relation to the driver's observation direction.

Legal regulations applicable in other countries are far from coherent: from complete prohibition of use across the entire country (Spain), through country specific (Holland, South Africa, Brazil) or local partial restrictions on selected parameters in force in specific states (Queensland, Victoria, New South Wales in Australia, New York, Virginia in USA), through specific cities (San Antonio, Oakdale in USA) and through no legal regulations whatsoever (numerous countries in Asia and Middle East).

The following are examples of requirements applying to such billboards, accepted by local self-governments, states and government bodies in countries which have already acknowledged the problem of outdoor billboards. Also, results of measurements of photometric and geometric parameters of selected billboards located in Poznań, Poland, have been presented, and recommendations for the operation of large size billboards with light emitting diodes have been formulated.

\section{Current legal situation in Poland}

The Polish lighting standards related to the lighting of work places located outdoors [1] and road lighting [2] do not specify requirements for large size billboards with light emitting diodes as objects impacting road traffic safety. The standard [1] consists of requirements on the limitation of interfering lighting, but they only address the reduction of inconvenience for people, animals and plants. The stipulations of the standard fail to address requirements related to driving (drivers of vehicles present in the road). Only maximum luminance and luminous intensity values of signs, including billboards emitting light (or illuminated ones) are specified. Unfortunately, the location of the billboard towards the observer, its angular diameter, distance from the main direction of observation and dynamic change of luminance (brightness) related to displayed images are not taken into account.

The Polish standard's [2] requirements related to glare limitation only apply to situations where small size light sources (luminaires) are present in the road. The evaluation of glare is carried out on the basis of the increase of the threshold 
value (TI). Consequently, such requirements may not be used when evaluating glare caused by large size billboards with light emitting diodes.

The currently valid ordinance of the Polish Ministry of Infrastructure [3] (point 79 applying to Art. 293 Para. 6) provides requirements for lighting devices, including billboards located outdoors or in the vicinity of buildings that may be inconvenient for pedestrians and drivers. Still, these requirements are not accurate and are no grounds to evaluate the level of inconvenience caused by billboards, especially for drivers. The ordinance specifies requirements on the illuminance of white light $(5 \mathrm{~lx})$ and color light $(3 \mathrm{~lx})$, but there is no description of the method of carrying out measurements in relation to both the location and external factors (impact of lighting in the road installation). Although the ordinance talks about drivers, these requirements seem to be applicable only to lighting causing inconvenience to residents.

\section{Review of requirements applicable to large size billboard with light emitting diodes}

Numerous countries carry out research on the impact of roadside billboards on reduced concentration of drivers. To a large extent, the research applies to traditional advertisement media, but there are in fact several papers on electronic advertisement [7]. Generally speaking, the results of all research projects indicate that billboards distract drivers. Several countries have implemented guidelines for issuing permits for installation of roadside billboards on the basis of results of such research projects, carried out mostly at the request of governmental bodies or road authorities. The following are the most important ones.

\subsection{Displaying moving images}

The issue of displaying moving images is well covered by world literature $[5,9$, 11]. Displaying moving images (animation, video) is explicitly forbidden. Electronic billboards may only display still images.

\subsection{Minimum billboard display time}

This issue raises disputes between billboard owners and road traffic safety specialists. A billboard owners' agenda is to present as many adverts in a given time unit as possible, provided the display time is long enough for the advert to be read and comprehended. There is no information on research projects aiming at evaluation of the impact of operation of billboards on distracting drivers. Different sources quote different times, but the data is not substantiated with empirical research. OAAA, Outdoor Advertising Association of America, an association of manufacturers of advertising media quotes a time of four seconds [9]. FHWA, the Federal Highway Administration operating in United States recommends a time of eight seconds [5]. Recommendations implemented in 41 states in North America specify a time from four to ten seconds [5]. The necessity to specify the minimum time of displaying adverts comes as a consequence of the so-called Zeigarnik effect occurring in case of sequentially 
appearing advertising messages, provoking the observer to observe the remaining part of the message, leading to a much worse concentration of the driver. This is to be prevented by a requirement saying that the observer (driver) is not supposed to observe changing images in the billboard, but rather is supposed to see the same still advert in the device [13]. The minimal time $t$ of displaying an advert should therefore be connected with the distance $d$ at which the advert is being observed and the speed limit $v$ introduced for the road in the vicinity of which the billboard is located. The analyzed literature suggests the following recommendation is applied (1):

$$
t=\frac{d}{v}
$$

where: $t$ - minimum advert display time [s], $d$ - distance from the billboard [m], $v$ - speed limit $[\mathrm{m} / \mathrm{s}]$.

\subsection{Visual effects and interval between consecutive images}

Generally, all available publications unanimously claim that there should be no delay between the changing images of consecutive adverts. Also, no visual effects should be used between the changing images. Images must not be dimmed, brightened, overlapping and animated [5].

\subsection{Amount of displayed information}

The longer the time the driver is forced to read an advert, the higher the threat to traffic safety. Research has proven [4] that drivers start reading advertising texts located at a distance of $250 \mathrm{~m}$ if the letters of the text are $45 \mathrm{~cm}$ high. Reading speed is assumed at one word per second, which gives a maximum number of 8 words at the speed of $90 \mathrm{~km} / \mathrm{h}, 7$ words at $100 \mathrm{~km} / \mathrm{h}$ and 6 words at $115 \mathrm{~km} / \mathrm{h}$. The number of words should be lower in unfavorable conditions (lower letters, reduced contrast). No specific recommendations have been specified with this regard. Still, it is known that the amount of information in the billboard should depend on the speed limit in the area and the distance to the billboard. Billboards should also not display website addresses, phone numbers and text message details.

\subsection{Brightness, luminance and illuminance}

Brightness is subjective, hence cannot be objectively measured. Electronic billboards seem less bright during the day than at night. Billboards seen at night, in city centers, seem less bright than the same billboards observed in dark, unoccupied surroundings. Electronic billboards made from electroluminescent diodes are original sources emitting light by themselves, hence luminance should be used to describe their properties.

Generally, there is no need to limit the luminance of billboards during the day, but there is no doubt such limits should be imposed for billboards at night. The so-called moth effect, described as unintentional directing of one's eyesight to the brightest objects in the field of view. Consequently, the brighter the 
surface of the billboard, the higher the danger it poses with regard to distracting the driver and leading their eyesight off the road [14].

The luminance of billboard surfaces may not be specified explicitly, as brightness (a subjective sensation) depends on the area of the billboard and the luminance of the surroundings. In general, all literature sources specify the billboard's luminance as the only value affecting the billboard's brightness. Only OAAA, Outdoor Advertising Association of America, an association of manufacturers of advertising media, specifies requirements for illuminance $[11,12]$.

A document titled "Technical Memorandum: Evaluation of Billboard Sign Luminances" was drawn up in 2008 by the Lighting Research Center, Rensselaer Polytechnic Institute at the request of the New York State Department of Transportation. The memorandum describes three stages of research: a review of recommendations for luminance calculation (on the basis of the paper by IESNA), measurements of luminance of existing billboards and a computer simulation of an electronic billboard. According to IESNA recommendations, the illuminance in the surface of an electronic billboard should be $1000 \mathrm{~lx}$ for bright surroundings, and $500 \mathrm{~lx}$ for dark surroundings. Assuming that the billboard surface coefficient of reflection of the light stream is 0.8 , this corresponds to luminance of $250 \mathrm{~cd} / \mathrm{m}^{2}$ and $130 \mathrm{~cd} / \mathrm{m}^{2}$. The paper's authors confirm that these assumptions are followed by billboard manufacturers. The authors have also measured existing billboards: six backlit billboards and four electronic billboards. The memorandum authors' own research led them to a conclusion that the luminance of a backlit billboard should not exceed $280 \mathrm{~cd} / \mathrm{sq} \mathrm{m}$ at night.

A document [15] listing requirements for roadside billboards has been developed at the request of the Traffic Engineering and Road Safety section of the Queensland (Australia) Government's Department of Main Roads. The document's characteristic features are several definitions. For example, roadside billboards are divided into four categories depending on their size and placement in relation to the road. Attachment D discusses the billboards' brightness, and quotes a paper [16] on backlit billboards. The paper claims that "the brightness of backlit roadside billboards should be limited under any conditions". The authors emphasize the difference between the concepts of brightness and luminance. Luminance is used for assessing the properties of a billboard as a device for displaying images. Luminance may be different in the billboard's surface (luminance distribution) and depending on the angle of observation. The highest luminance occurs when observing the billboard from straight ahead and is reduced as the angle of observation increases. Brightness is a subjective visual sensation, whose intensity depends on the luminance of the billboard's surface (luminance distribution), the size of the billboard, the contrast (in relation to background luminance), the observer's position and the observer's adaptation. The document presents the maximum permissible, average luminance of the billboard's surface for three areas (tab. 1).

The reduction of the billboard's surface luminance is not required at night only, but also in certain situations during the day. In case of a fog, bright billboard surfaces may hamper the drivers' vision. To ensure luminance is 
Table 1: $\quad$ Permissible luminance values of billboards' surfaces according to [15].

\begin{tabular}{|c|l|c|}
\hline $\begin{array}{c}\text { Area } \\
\text { number }\end{array}$ & \multicolumn{1}{|c|}{ Description } & $\begin{array}{c}\text { Permissible } \\
\text { luminance value }\end{array}$ \\
\hline 1 & $\begin{array}{l}\text { Area with high level of lighting, not caused by road lighting system, } \\
\text { e.g. city centers. }\end{array}$ & $500 \mathrm{~cd} / \mathrm{m}^{2}$ \\
\hline 2 & $\begin{array}{l}\text { Area with average level of lighting, not caused by road lighting } \\
\text { system, e.g. suburban industrial areas, filling stations, parking lots. }\end{array}$ & $350 \mathrm{~cd} / \mathrm{m}^{2}$ \\
\hline 3 & $\begin{array}{l}\text { Area with low level of lighting, not caused by road lighting system, } \\
\text { e.g. rural areas, residential areas. }\end{array}$ & $300 \mathrm{~cd} / \mathrm{m}^{2}$ \\
\hline
\end{tabular}

reduced during fog, it may not be enough to equip billboards with photodetection devices reducing their luminance at night. Other dedicated requirements for such situations may have to be implemented.

\subsubsection{Permits}

Authorities issuing permits should be able to analyze annually the impact of electronic billboards on road traffic safety in a given location. Also, the billboard's properties may alter when its elements or software are changed. Ultimately, new requirements may be accepted (on the basis of newly conducted research), which may lead to the change of, e.g. billboards' luminances. It is recommended [5] to follow the method used by Oakdale, Minnesota, authorities [10]. The billboard's investor (owner, operator) obtains a one-year permit to operate the billboard and is required to renew it annually.

\section{Research of large size billboards with light emitting diodes in Poznań}

In the summer of 2010, over thirty large size billboards with light emitting diodes have been located in the administrative territory of the town of Poznan.

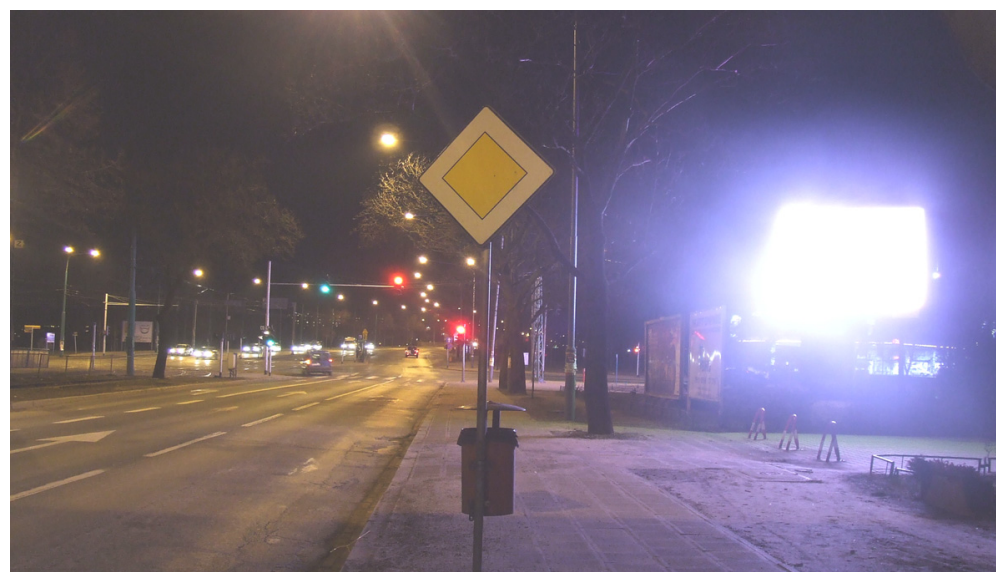

Figure 2: $\quad$ View of a very bright billboard at night. 
These billboards are usually large, very bright and show dynamically changing images whose brightness varies greatly (videos, animated images), especially at night. Figure 2 shows an example of a very bright billboard with light emitting diodes.

Billboards with light emitting diodes are usually installed in places where the daily traffic is very high (city centers, high streets, intersections, roundabouts see fig. 4), and thus significantly impact the drivers' vision conditions, leading to reduced concentration and even glare. Thus, they are a potential threat to road traffic safety. Figure 3 shows an example of location of a billboard near an intersection.
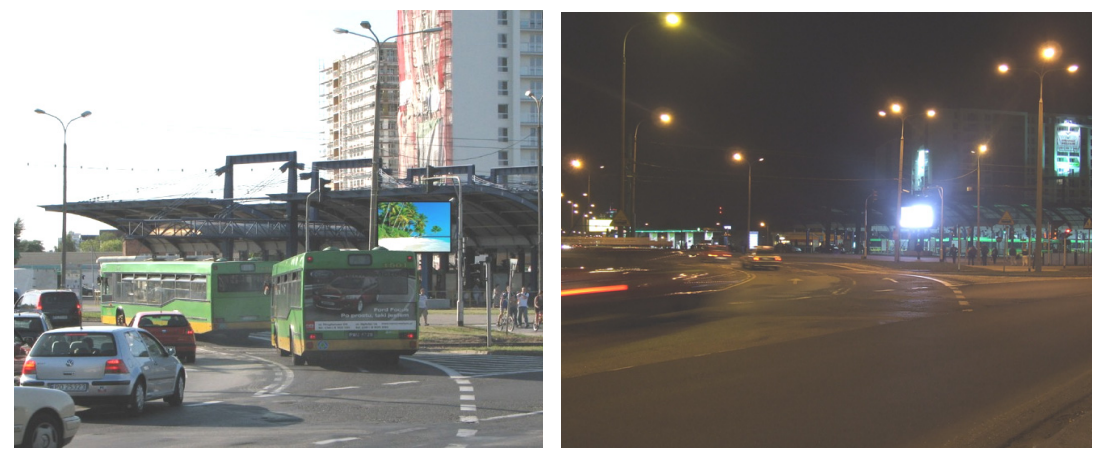

Figure 3: A billboard located in a place where daily traffic is high (as seen during the day and at night).

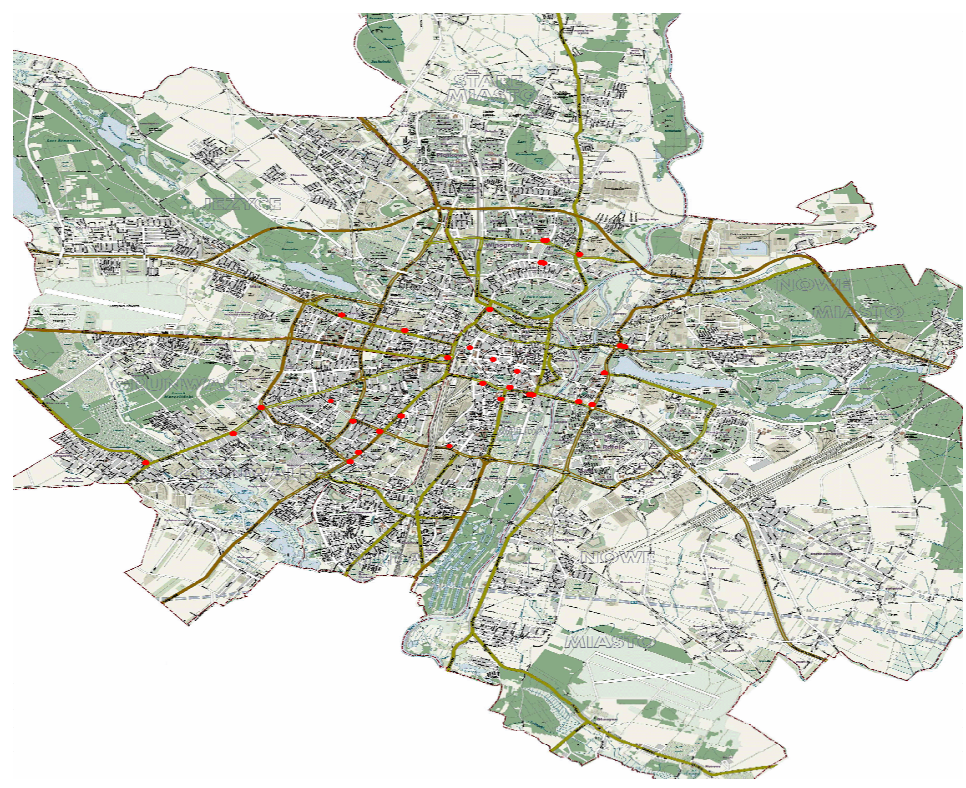

Figure 4: Location of large size billboards with light emitting diodes in Poznań, Poland. Status as of August 2010. 
Figure 4 shows approximate location of billboards in Poznań. Measurements of properties of large size billboards with light emitting diodes have been carried out for 18 billboards located in Poznań. The measurements have been carried out after sunset, as billboards impact drivers' vision the most at night. All examined billboards have been located in the drivers' fields of view, $1.5 \mathrm{~m}$ to $13 \mathrm{~m}$ above ground. All billboards were large and showed dynamically changing images, except for a single billboard showing still images. The surface of the largest billboard was approximately $30 \mathrm{~m}^{2}$, and approximately $5 \mathrm{~m}^{2}$ for the smallest one. Table 2 shows the highest and lowest values of the measured geometric parameters and average values for all billboards.

Table 2: Highest and lowest values of the measured geometric parameters and average values for examined billboards.

\begin{tabular}{|c|c|c|c|}
\hline $\begin{array}{c}\text { Billboard's } \\
\text { geometric } \\
\text { parameter }\end{array}$ & $\begin{array}{c}\text { Average } \\
\text { value } \\
\text { for all } \\
\text { billboards }\end{array}$ & $\begin{array}{c}\text { Highest of } \\
\text { measured } \\
\text { values }\end{array}$ & $\begin{array}{c}\text { Lowest of } \\
\text { measured } \\
\text { values }\end{array}$ \\
\hline height $[\mathrm{m}]$ & 3.1 & 4.8 & 1.2 \\
\hline width $[\mathrm{m}]$ & 4.9 & 6.3 & 2.9 \\
\hline surface $\left[\mathrm{m}^{2}\right]$ & 15.2 & 30.1 & 5.4 \\
\hline
\end{tabular}

A site plan showing the location of the measurement point, main observation directions and the location of the billboard in relation to the road has been drawn up during the measurements. The main directions of observation of the surface of the billboard were selected following the analysis of the location of the billboard in relation to the layout of the street and the traffic system (one-way streets, no turn or turn only signs). The location of measurement points was based on the assumed division of angles, for which the billboard's luminance was measured and possibilities of taking practical measurements were assessed. Figure 5 shows examples of site plans of two measurement points.

The measurement of photometric parameters included the measurement of the luminance of the billboard's central point, the luminance of the surface of the road as the adaptive surface for road users and the luminance of the billboard's background. The luminance of the billboard's central point was measured in plane perpendicular to the surface of the billboard's measurement point. The billboard's maximum and minimum luminance in this point was measured. The change of luminance in the billboard's central point depending on four different angles of observation in relation to the plane perpendicular to the surface of the billboard was measured. The road surface average luminance was measured for the lane of traffic moving towards the billboard. The billboard's background luminance was measured for surfaces located in its closest vicinity and for the horizon in the back of the observed billboard.

Table 3 presents the summary of luminance measurements, and a selected distribution of luminance in the billboard's surroundings is shown in fig. 6 . 

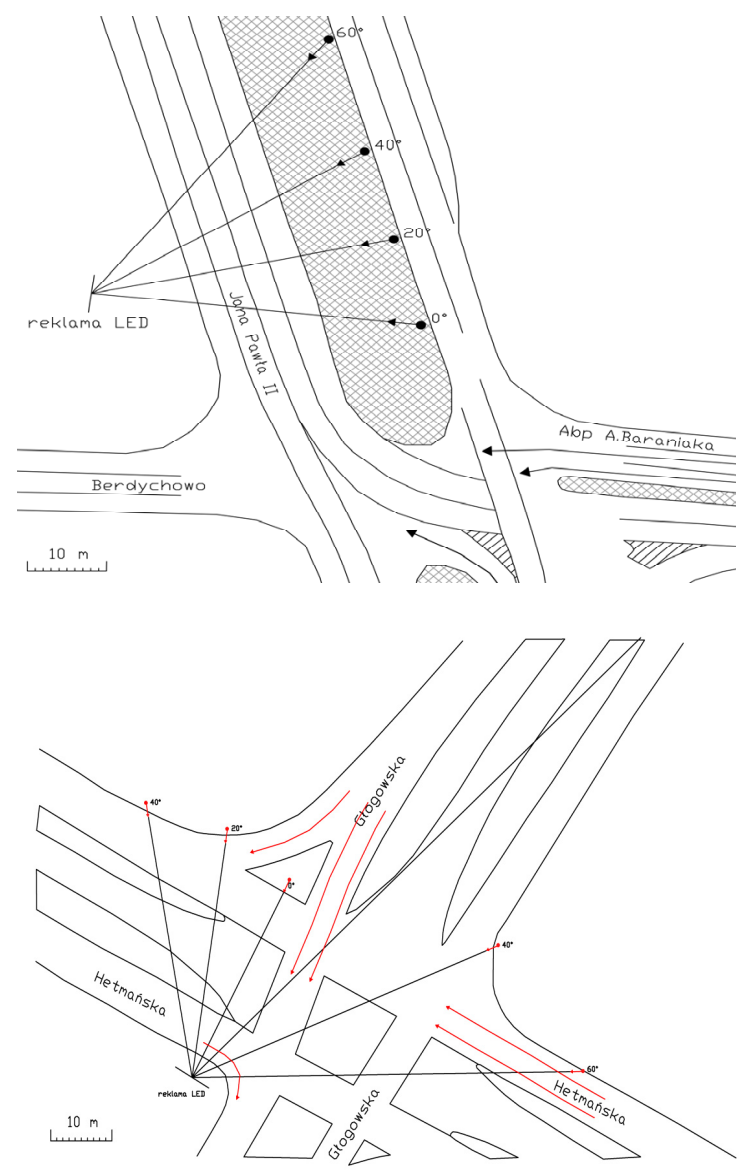

Figure 5: Street layout indicating the examined billboard and locations of measurement points for angles $0^{\circ}, 20^{\circ}, 40^{\circ}, 60^{\circ}$ and main directions (marked with arrows in traffic lanes).

Table 3: $\quad$ List of measured luminance values.

\begin{tabular}{|c|c|c|c|}
\hline Luminance $\left[\mathrm{cd} / \mathrm{m}^{2}\right]$ & $\begin{array}{c}\text { Average value for } \\
\text { all billboards }\end{array}$ & $\begin{array}{c}\text { Highest of } \\
\text { measured values }\end{array}$ & $\begin{array}{c}\text { Lowest of } \\
\text { measured values }\end{array}$ \\
\hline $\begin{array}{c}\text { maximum for billboard's } \\
\text { central point }\end{array}$ & 1983 & 7953 & 377 \\
\hline billboard surroundings & 9.3 & 108 & 0.9 \\
\hline horizon & 1.8 & 6.5 & 1.1 \\
\hline road surface & 3.1 & 4.6 & 0.2 \\
\hline
\end{tabular}




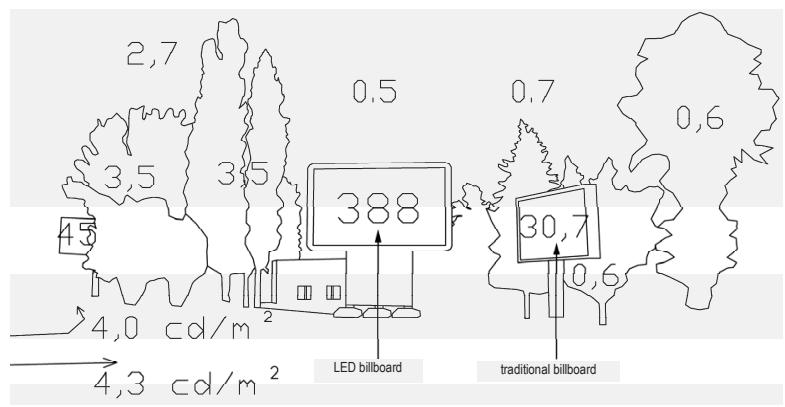

Figure 6: Selected distribution of luminance $\left(\mathrm{cd} / \mathrm{m}^{2}\right)$ in the vicinity of a billboard with light emitting diodes.

The change of luminance of billboards depending on observation angle was also changed (fig. 7).

\section{Analysis of obtained results}

The measurements of properties of large size billboards with light emitting diodes confirmed the existence of high values of luminance of billboard surfaces at low values of luminance of the vicinity of the billboards. If a value of 500 $\mathrm{cd} / \mathrm{m}^{2}$ suggested in $[15,16]$ and presented in tab. 1 is assumed as a criterion of evaluation of permissible values of luminance for high illuminance surfaces, then only 2 out of the examined 18 billboards meet this requirement. The two billboards had maximum luminance of $377 \mathrm{~cd} / \mathrm{m}^{2}$ and $388 \mathrm{~cd} / \mathrm{m}^{2}$. The remaining billboards luminance was from $554 \mathrm{~cd} / \mathrm{m}^{2}$ to $814 \mathrm{~cd} / \mathrm{m}^{2}$ (6 billboards) and over $1000 \mathrm{~cd} / \mathrm{m}^{2}$ - from $1051 \mathrm{~cd} / \mathrm{m}^{2}$ to $7953 \mathrm{~cd} / \mathrm{m}^{2}$ (10 billboards). The average luminance of the surface of all examined billboards was $1983 \mathrm{~cd} / \mathrm{m}^{2}$, given the average background luminance below $10 \mathrm{~cd} / \mathrm{m}^{2}$ and average road surface luminance, namely adaptive luminance, of approximately $3 \mathrm{~cd} / \mathrm{m}^{2}$. Almost all examined billboards featured highly variable parameters and high luminance contrasts of the displayed images. The highest value of luminance contrast, defined as the relation of the luminance of the object to the luminance of the background, was over 4000 .

The obtained results show it is necessary to impose limits for billboard luminance values at night.

The measurements of changes of luminance of billboards' central points depending on the angle of observation in relation to perpendicular plane allowed us to distinguish three groups of billboards differing in the dependence of the change of luminance on the change of observation angle. Figure 7 presents average results for these groups. 


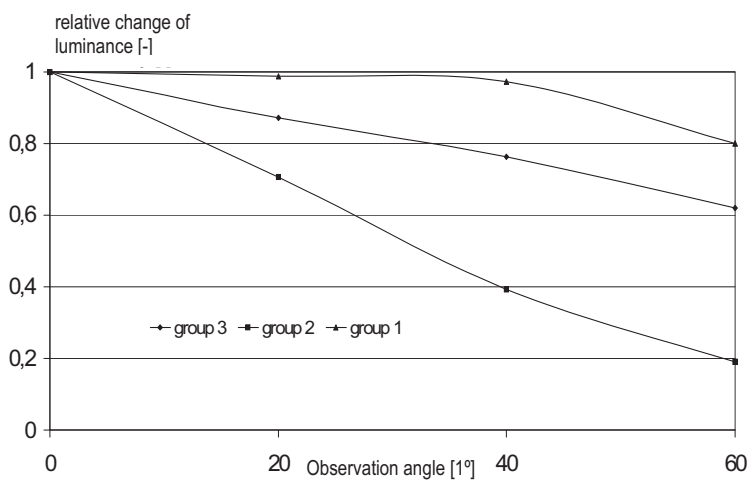

Figure 7: Relative changes of luminance in the billboard's central point depending on the angle of observation in relation to the plane perpendicular to the surface of the billboard.

The calculated characteristics of the change of luminance depending on the angle of observation in relation to the perpendicular plane and the know maximum luminance make it possible to specify a permissible (subject to possibility of glare) location of a billboard with light emitting diodes in relation to observation angles.

\section{Conclusions}

The completed measurements and their analysis have shown the negative impact of large size billboards with light emitting diodes on drivers' vision conditions, especially at night, and consequently on road traffic safety. Factors resulting in negative impacts of such billboards may be divided into two categories:

- Factors related to photometric parameters of large size billboards and their immediate surroundings influencing the vision process:

- high luminance of billboards with light emitting diodes at low background luminance - favorable conditions causing glare among drivers,

- high contrast of displayed images causing glare among drivers,

- Factors related to perception of adverts and the process of seeing the road:

- dynamically changing images (video, animations, rapidly dimmed or brightened images) that distract drivers,

- displaying content intended for memorization (addresses, phone numbers, mails),

- location of billboards where increased concentration is required (intersections, roundabouts, road vicinity),

- placing billboards at low heights in relation to the ground, making it difficult to spot road traffic signs. 
On the basis of research results, experience and the analysis of recommendations discussed in other papers, the researchers suggest that requirements and limits related to large size billboards with light emitting diodes presented in table 4 are introduced. These recommendations are discussed in detail in the report [17].

Table 4: List of recommendations for large size billboards with light emitting diodes.

\begin{tabular}{|c|c|}
\hline Name & Recommendation \\
\hline $\begin{array}{c}\text { Maximum luminance of } \\
\text { billboard surface }\end{array}$ & $\begin{array}{c}\text { At night } 400 \mathrm{~cd} / \mathrm{m}^{2} \\
\text { During the day } 5000 \mathrm{~cd} / \mathrm{m}^{2}\end{array}$ \\
\hline Billboard location & $\begin{array}{c}\text { Within } 90^{\circ}-180^{\circ} \text { in relation to road surface border } \\
\text { Unacceptable emission of light towards locations } \\
\text { with higher risk of road collisions } \\
\text { Outside intersections }\end{array}$ \\
\hline Displaying moving images & Prohibited \\
\hline Minimum advert display time & 10 seconds \\
\hline Issuing permits & Temporary, for one year \\
\hline $\begin{array}{c}\text { Visual effects and interval } \\
\text { between consecutive images }\end{array}$ & Prohibited \\
\hline Type of displayed information & Addresses, websites, emails, phone numbers, text \\
message instructions
\end{tabular}

\section{References}

[1] Polish Standards: PN-EN 12464-2:2008 Światło i oświetlenie. Oświetlenie miejsc pracy. Część 2: Miejsca pracy na zewnątrz, (pol.)

[2] Poilsh Standards: PN-EN 13201-3:2007 Oświetlenie dróg, (pol.).

[3] Rozporządzenie Ministra Infrastruktury z dnia 12 marca 2009 zmieniające rozporządzenie w sprawie warunków technicznych, jakim powinny odpowiadać budynki i ich usytuowanie, (pol.).

[4] Dudek, C.L.: Changeable Message Sign Displays During Non-Incident, Non-Roadwork Periods: A Synthesis of Highway Practice. NCHRP Synthesis 383. Washington, DC: Transportation Research Board, 2008.

[5] Wachtel, J.: Safety Impacts of the Emerging Digital Display Technology for Outdoor Advertising Signs. Submitted Under NCHRP Project 20-7 (256). April, 2009.

[6] IESNA: Technical Memorandum on Light Trespass: Research, Results and Recommendations. IESNA TM-11-2000. 
[7] Lee, S.E., McElheny, M.J. \& Gibson, R.: Driving Performance and Digital Billboards. Center for Automotive Safety Research, 2007.

[8] Farbry, J., Wochinger, K., Shafer, T., Owens, N. \& Nedzesky A.: Research Review Of Potential Safety Effects of Electronic Billboards on Driver Attention and Distraction. Science Applications International Corporation, 8301 Greensboro Drive, USA.

[9] Inquiry into Driver Distraction. Road Safety Committee. Parliament of Victoria, Australia, 2006.

[10] Zillmer, K.: Oakdale ready for latest billboards - City passes dynamic sign ordinance. Oakdale Lake Elmo Review, 2008.

[11] Lewin, I.: Digital Billboard Recommendations and Comparisons to Conventional Billboards. Lighting Sciences Inc.

[12] Digital billboards and road safety: An analysis of current policy and research findings. Outdoor Media Association Inc.

[13] Chan, E., Pradhan, A.K., Knodler, M.A., Pollatsek, A. \& Fisher, D.L.: Evaluation on a Driving Simulator of the Effect of Drivers' Eye Behaviors from Distractions inside and Outside the Vehicle. Human Factors, 2008.

[14] Green, M.: Is the moth effect real? Accident Reconstruction, May/June, pp. 18-19, 2006.

[15] TERS: Guide to the Management of Roadside Advertising, Edition 1.0. TERS Product No. 80-500. Queensland Government, Department of Main Roads, 2002.

[16] Johnson, A. \& Cole, B.: Investigations of Distraction by Irrelevant Information. Australian Road Research, 6(3), 1976.

[17] Domke, K., Wandachowicz, K., Zalesińska, M,. Mroczkowska, S. \& Skrzypczak P.: Ocena zagrożeń występujących w ruchu drogowym powodowana przez wielkopowierzchniowe reklamy z diodami świecącymi. Raport z badań (pol.), Poznan University of Technology, 2010. 